\title{
KARIŲ IR CIVILIŲ BENDRADARBIAVIMUI SKATINTI TAIKOMOS PRIEMONÉS IR JŲ VEIKSMINGUMAS
}

\author{
Miglè Nemanytė \\ Lietuvos kariuomenès Mechanizuotosios pèstininkų brigados „,Geležinis Vilkas“ \\ Kunigaikščio Vaidoto mechanizuotasis pèstininku batalionas
}

Doc. dr. Jūratė Guščinskienė

Generolo Jono Žemaičio Lietuvos karo akademija

\begin{abstract}
Anotacija. Publikacijoje atkreiptas demesys $i$ kariu ir civiliu bendradarbiavimo svarba taikos metu. Jis vyksta stiprinant viešuosius ryšius, taikant ịvairias šiems ryšiams büdingas priemones, nes Lietuva neturi savo nacionalinès kariu ir civiliu bendradarbiavimo koncepcijos, skirtos taikos metui. Straipsnyje apžvelgti teisiniai dokumentai, reglamentuojantys kariu ir civiliu bendradarbiavima, pristatyti empirinio tyrimo (interviu), atlikto Lietuvos kariuomenès Mechanizuotosios péstininku brigados „, Geležinis Vilkas “ Kunigaikščio Vaidoto mechanizuotajame péstininku batalione, rezultatai. Jo metu buvo siekiama sužinoti informantu nuomonę apie civiliu ir kariu bendradarbiavimo svarba užtikrinat Lietuvos sauguma, taip pat ju požiūrị i taikomas bendradarbiavimo priemones ir ju veiksminguma.
\end{abstract}

Reikšminiai žodžiai: kariu ir civiliu bendradarbiavimas, taikos metas, viešieji ryšiai, bendradarbiavimo priemones.

\section{Ivadas}

Per pastaruosius keletą šimtmečiu tarpusavio civilinès ir karinès sąveikos normos, kurios buvo įtvirtintos ir paremtos Vakaru pilietine mintimi ir politine tvarka, keičiasi. Tai lèmė XX a.-XXI a. pradžioje civilių tapimas karo dalyviais. Kariuomenè susiduria su naujomis užduotimis, pavyzdžiui, humanitarinès pagalbos operacijų rajone teikimu, kartu išlaikant militarizuotą erdvę, kombatanto nuo ne kombatanto atskyrimu ir kitomis. Taigi neretai karinio konflikto metu ribos tarp nekarinio ir karinio veikèjo išnyksta, o civiliai tampa ne tik aukomis, bet ir taikiniais. Amerika jau po Antrojo pasaulinio karo sukūrẻ karinius vienetus, kurių viena funkcijų buvo civiliniai reikalai (angl. public affair). XX a. antrojoje pusèje NATO šalys po Bosnijos ir Hercegovinos karo taip pat pradejo kurti savo kariu ir civiliu bendradarbiavimo struktūras. NATO patirtis tarptautinèse operacijose parode karių ir civilių bendradarbiavimo poreikio svarbą ir tai, kad karas nèra vien kariškių 
reikalas. „Bosnijos pamokos“ Balkanų regione lėmè ir NATO karių ir civilių bendradarbiavimo doktrinos pokyčius. NATO intervencija Afganistane (nuo $2001 \mathrm{~m}$.) parodè, kad konfliktai ịžengè ị kitą ir visai naują fazę - atsirado poreikis gilintis ị vietos kultūrą, gyvenimą, kurti tarpasmeninius ryšius su vietos bendruomenèmis, kad būtų pasiekti kariniai, o po to ir politiniai tikslai (Zartsdahl, 2018).

NATO pripažista, kad kariuomenẻ savaime negali išspręsti krizès ar konflikto, kadangi šiuolaikiniai konfliktai apima daug daugiau nei vien kariuomenę: jie veikia ekonominę, socialinę, technologinę, religinę, etninę ir ideologinę aplinką (NATO, NATO CIMIC Handbook, 2019). Krizių / konfliktų užduotys ir jų valdymo reikalavimai išsiplète priklausomai nuo susijusių nekarinių dalyvių ịsitraukimo. Keičiantis pasaulio politikos ir saugumo kontekstui, kinta ir kai kurios kariuomenès užduotys. Tai atsispindi karių ir civilių bendradarbiavimo srityje. Susiklosčiusiame nacionalinio saugumo kontekste, ypač po Krymo aneksijos (2014 m.), Lietuva turèjo imtis priemonių tam, kad priešiškai nusiteikusios valstybès veiksmams būtų parengta ne tik visa krašto apsaugos sistema, bet ir kiekvienas šalies pilietis. Prieš galimą konfliktą (taikos metu) imamasi naujų karių ir civilių bendradarbiavimo priemonių, t. y. viešųų ryšių, kurie apima šias sritis: kariuomenès bendravimą su žiniasklaidos atstovais, civilių švietimą ir įtraukimą ị ịvairius renginius, dalijimąsi karinio gyvenimo aktualijomis internete ir socialinèse platformose, informacijos apie kariuomenès veiklą skleidimą, tarpinstitucinį bendradarbiavimą su vietos savivaldybėmis, nevyriausybinėmis ir kitomis organizacijomis ir kt. Viešieji ryšiai, nukreipti ị pilietinès valios, patriotiškumo ir pilietiškumo ugdymą, yra šalies nacionalinio saugumo garantas.

Tyrimo problemą nusako šie klausimai: Ar kariai ir civiliai yra linkę bendradarbiauti? Kokios priemonès taikomos karių ir civilių bendradarbiavimui palaikyti? Kurios priemonès yra veiksmingiausios?

Tyrimo objektas - karių ir civilių bendradarbiavimo priemonès.

Tyrimo tikslas - ištirti karių ir civilių bendradarbiavimui skatinti taikomas priemones ir jų veiksmingumą.

Tyrimo uždaviniai: 1) paaiškinti karių ir civilių bendradarbiavimo sampratą; 2) išanalizuoti karių ir civilių bendradarbiavimo svarbą šiuolaikinei krašto gynybai; 3) nustatyti Kunigaikščio Vaidoto mechanizuotajame pėstininkų batalione naudojamas karių ir civilių bendradarbiavimo priemones ir jų veiksmingumą.

Tyrimo metodai: mokslinès literatūros ir teisinių dokumentų analizè, interviu.

\section{Karių ir civilių bendradarbiavimo samprata}

Kaip rašè karo teoretikas C. von Clausewitzas, karas - tai politika, tik kitomis priemonėmis. Tai reiškia, kad kare dalyvauja ne tik kariuomenè, kaip jègos struktūra, bet ir visa civilinè bendruomenè, kuri taip pat suteikia valdžią vieniems ar kitiems politikams. Karą tarp žmonių visada lemia pilietiniai motyvai (Clausewitz, 2008). Nors pripažįstama, kad tarp karių ir civilių santykių nėra aiškiai nubrežztu linijų, būtent čia turètų žinios ir supratimas, kaip turètų būti stiprinamas šalies sau- 
gumas, sutapti (Morgan, 2002).

Karių ir civilių santykiai, pagal S. Huntingtono teoriją, suvokiamas kaip vienas iš nacionalinio saugumo politikos aspektų. Nacionalinio saugumo politika yra kuriama valstybės vadovų, siekiant saugoti ,socialines, ekonomines ir politines institucijas" nuo grèsmių (Hungtinton, 1957). Karių ir civilių santykiai darosi ramūs ir nusistoveję tada, kai šie supranta vieni kitų vaidmenị. Minètas autorius aprašè pirmają modernią Amerikos civilių ir karių santykių teoriją. S. Huntingtonas pripažino tvyrančią itampą tarp karinio funkcinio imperatyvo ir vyraujančių visuomenės kultūros, vertybių imperatyvo, standartų. Jis, kaip ir kiti ekspertai, pripažino civilinès kontrolès kariuomenei poreikị. Taip pat autoriaus akcentuoja, kad kariuomenès ir civilių santykiai yra ir ideologiniai. Šiuo lygmeniu pagrindinis klausimas - kaip kariuomenès etika dera su dominuojančiais politiniais idealais bei visuomene.

Anot J. Andersono harmonijos (angl. concordance) teorijos, kariu ir civiliu santykiai turètų pabrèžti ne tik institucinį vyriausybès ir karinių pajègų bendradarbiavimą, bet ir kultūrines problemas. Pagal minètą teoriją, karinèje ir civilinėje lygtyje yra trys pagrindiniai elementai: kariškiai, politinis elitas ir piliečiai, kurie turètu siekti bendradarbiauti. Svarbiausia, kad kultūriniai ir istoriniai veiksniai darytų įtaką karių ir civilių santykiams, nes nuo to priklausytų karinių ir civilinių institucijų atskyrimas ar integracija. Pagrindinè autoriaus idèja yra tai, kad kariuomenè turètu būti fiziškai ir ideologiškai atskirta nuo politinių institucijų (Anderson, 1998).

Pagal J. W. Leyd (1972) susiliejimo (angl. fusion) teoriją, kariuomenè, kaip nacionalinio saugumo ir gynybos dalis, negali būti atskirta nuo socialinès, ekonominès ir politinès sričių. Kariuomenei kaip tik labai svarbus profesionalumas, apimantis socialinį, politinị ir ekonominị lygị, o pagrindinis šios idejos „receptas“civilizuoti kariuomenę ir militarizuoti civilius.

Civilių ir kariuomenès santykiai nagrinèjami įvairiais aspektais ir aiškinami skirtingomis teorijomis. Vienos jų teigia, kad kariuomenès veikla turètų būti atskirta nuo politikos ir civiliai turètų kontroliuoti ginkluotąsias pajègas, kitos kad kariuomenè ir ekonominè, socialinè, politinè sritys nèra atskiros, kadangi visos jos yra šalies saugumo dalis. Tačiau gyvenant XXI a. kyla naujų iššūkių tiek kariams, tiek civiliams sprendžiant bendrus saugumo klausimus. Kadangi Lietuva yra didžiausios tarptautinès politinès ir karinès gynybinès organizacijos - NATO (angl. North Atlantic Treaty Organization, toliau - NATO) nare nuo 2004 m., šalies bendra gynybos ir nacionalinio saugumo politika yra neatsiejama nuo Aljanso organizacijos politikos ir tikslų. Dél šios priežasties Lietuva taip pat vadovaujasi NATO oficialiai patvirtintais dokumentais, strategijomis, tarptautine kitų šalių patirtimi. Vienas pagrindinių strateginių dokumentų, analizuojant kariuomenès ir visuomenès bendradarbiavimą, yra NATO CIMIC doktrina. Pagal NATO CIMIC doktriną (NATO, 2018) ir jos papildymą (Civil-Military Cooperation Centre of Excellence, 2019), kariuomenès ir visuomenès bendradarbiavimas (angl. CivilMilitary Cooperation, toliau - CIMIC) aiškinamas kaip jungtinè (angl. joint) funkcija, apimanti integralius pajègumus, kurie yra neatsiejami nuo misijos objekto ir 
leidžia NATO vadovams veiksmingai dalyvauti įvairaus pobūdžio karinèje ir civilinèje sąveikoje su nekariniais veikejjais. Tai grupe įvairių veiklų, pagrịstų karinių ir nekarinių veikejjų, įskaitant vietines populiacijas, nevyriausybines organizacijas ar agentūras, siekiant kuo efektyviau reaguoti ị krizes, komunikacija, planavimu, koordinavimu. Kalbant apie CIMIC, šis idealus karių ir civilių bendradarbiavimo tipas reiškia, kad kariškiai vadovauja humanitariniams reikalams (Angstrom, 2013).Taip pat reikètų pabrèžti, kad karių ir civilių bendradarbiavimą galima suprasti ne tik kaip dokumentais pagrịstą procesą, bet ir kaip filosofiją, mąstyseną, tam tikrą kultūrą (Noble, 2008, p. 191). Svarbu suvokti tai, kad CIMIC doktrina nurodo įvairiausio kariuomenès ir visuomenès bendradarbiavimo gaires konflikto ir (ar) humanitarinès pagalbos teikimo metu. Ši doktrina aprašo J9/G9 viešujų ryšių padalinio veiklą kariniame vienete (pavyzdžiui, divizijos, brigados lygmeniu), ị kurią savo ruožtu įtraukia ir kitus skyrius, susijusius su planavimu, ryšiais, žvalgyba, logistiniu aprūpinimu. CIMIC personalo skaičius labai priklauso nuo pajègų dydžio ir užduoties.

Tačiau pagrindinè problema, kalbant apie NATO CIMIC doktriną, yra ta, kad ji apibrěžia karių ir civilių bendradarbiavimą tik konflikto, operacijų metu, o dar iki tol civilinè visuomenè turi būti paruošta ginti savo šalị (nebūtinai ginklu) ir palaikyti šalies ginkluotąsias pajëgas. Deja, kol kas nèra strateginių gairių, kaip elgtis, kokių priemonių ir metodų imtis taikos metu užtikrinant karių ir civilių bendradarbiavimą. Svarbu tai, kad visuomenès pasitikèjimas ginkluotosiomis pajėgomis, kaip nacionalinio saugumo užtikrinimo institucija, turi didelę reikšmę ir yra tiesiogiai susijęs su valstybès funkcionavimu. Tiek ginkluotosios pajegos, tiek civilinè visuomenė nori veikti atvirai, darniai, skaidriai ir bendradarbiaudamos. Pačios ginkluotosios pajègos gali būti išlaikytos kaip institucija tik tuo atveju, jei jos vykdo visuomenès reikalavimus. Pagrindinè ginkluotujų pajėgų misija šiuo laikotarpiu atspindima naudojant žiniasklaidos, socialines ir kitas informavimo, komunikavimo priemones (Brožič, 2013). Dèl šios priežasties viešieji ryšiai (angl. public relations) tapo karių ir civilių bendradarbiavimo priemone taikos metu. İvairius viešujų ryšiu tematikos aspektus gvildeno A. Gregory (2003), R. L. Heath (2005), J. Hoffmann (2019), J. O’Neil ir kt. (2020) ir kiti. Dalis tyrejjų savo dèmesị sutelke ị viešųų ryšių kariuomenejje klausimo analizę, pavyzdžiui, V. Gruber (2015), C. C. Moskos (2000), G. D. L. Jeeni ir kt. (2015) ir kiti.

Viešieji ryšiai - tai strateginès komunikacijos proceso dalis, kuri kuria naudingus santykius tarp tam tikros organizacijos ir jos auditorijos (Forsey, 2018). Dél šios priežasties Lietuvos Respublikos (LR) krašto apsaugos ministras patvirtino 2011 m. Nr. V-146 ịsakymą „Dèl Krašto apsaugos viešųų ryšių gairių tvirtinimo“, kuriame numatytos krašto apsaugos sistemos (KAS) viešujų ryšių kryptys, apimančios komunikaciją su civiliais, taip pat tarpinstitucinis bendradarbiavimas ir jo ịgyvendinimo priemonès:

1. Aktyviai bendradarbiauti su žiniasklaida - ne tik patiems atsakyti i jų klausimus, bet ir inicijuoti informacijos apie savo veiklą teikimą.

2. Sudaryti galimybes žiniasklaidos atstovams ir kitiems viešosios informa- 
cijos rengèjams domètis ir igyti žinių apie gynybos politiką, skatinti jų motyvaciją domètis KAS.

3. Šviesti KAS tarnautojus apie galimas nacionalinio saugumo grèsmes ir politiką, KAS veiklą. Tam naudoti įvairias priemones: renginius, susitikimus, internetą.

4. Plètoti veiklą su švietimo įstaigomis per viešujų ryšių projektus, bendradarbiauti rengiant vadovèlius (pvz., kaip piliečiai turètų elgtis krizių, ekstremalių situacijų, konflikto metu ir kt.), organizuoti pamokas ar paskaitas mokyklose, rengti mokinių konkursus, šviesti mokytojus kvalifikacijos kèlimo centruose, ị aukštuju mokyklų programas įtraukti mokomajį dalyką apie saugumą ir gynybą.

5. Kurti ir plètoti bendradarbiavimą su savivaldybių institucijomis ir vietinèmis bendruomenemis.

6. Skirti dèmesio internetui, oficialiems KAS puslapiams, kur viešinama visiems prieinama informacija. Pagal LR krašto apsaugos ministro įsakymą „Dèl krašto apsaugos sistemos interneto svetainès koncepcijos“, kariuomenès interneto svetainių dizainas turi būti šiuolaikiškas, santūrus, demonstruojantis atviros visuomenès ịvaizdį. Šiomis svetainėmis turètų naudotis kariai ir civiliai, todèl svarbu, kad jos būtų patogios. Jose skelbiama informacija turi atitikti tikrovę ir būti dinamiška, aktuali ir suprantama visuomenei.

7. Organizuoti karių ir civilių renginius (kariuomenès ir visuomenès dienas ịvairiuose Lietuvos miestuose ir kt.), sudarant galimybę visuomenei tiesiogiai susipažinti su kariuomenès veikla.

8. Filmuoti ir fotografuoti svarbiausius KAS ịvykius, o vaizdo medžiagą platinti kartu su tekstu ịvairiomis informavimo priemonemis, interneto puslapiuose, socialiniuose tinkluose ir kt.

9. Verbuoti jaunimą ị nuolatinę privalomają pradinę karo tarnybą (toliau NPPKT), taikant ịvairias verbavimo priemones, pradedant finansinèmis išmokomis, baigiant reklamos kampanijomis.

\section{Karių ir civilių bendradarbiavimo svarba šiuolaikinei krašto gynybai}

Atkūrus nepriklausomybę Lietuva perėmė vakarietiškas ịvairių veiklos sričių tradicijas, taip pat ir karybos. Anot D. Šlekio (2015, p. 215), „,ivilių ir karių santykiai turi nemenkų defektų bandant realizuoti vakarietiško tipo kariuomenès kontrolès modelị. Keičiantis laikmečiui, turètų būti keliami tokie fundamentalūs klausimai: kas yra karas ir kaip keičiasi jo pobūdis, kaip keičiasi sajungininkų ginkluotuju pajègu politika ir kaip tai veikia mus, o svarbiausia, kad klausimas turètų būti keliamas ne tik karinèje, bet ir didesnèje - civilinèje bendruomenèje tam, kad turètume lanksčią civilinę kariškių bendruomenę. Po nepriklausomybès atkūrimo Lietuva susidūrè su nemenku iššūkiu, kadangi vienu metu reikejjo iš naujo kurti ir funkcionuojančias karines pajègas, ir teisinę institucinę sistemą, kuri sudarytų sąlygas užtikrinti ginkluotųjų pajėgų demokratinę civilinę kontrolę. Kadangi kariuomenè yra 
gana uždara jègos struktūra, nepaisant valstybès režimo, visais laikais civiliai siekè kontroliuoti kariuomenę. Tačiau galima teigti, kad per pirmajį nepriklausomybės dešimtmetị Lietuva perèmè vakarietišką - institucinị civilių ir kariškių modelị.“ Šiais laikais turime sklandžiai funkcionuojančią teisinę bazę, reguliuojančią tiek visuomenès, tiek kariuomenès gyvenimą, santykius, veiklas bei funkcijas. Tačiau, kaip teigia D. Šlekys (2015), gerai funkcionuojančios teisinès bazės nepakanka, reikia, kad būtų kuriama atitinkama civilių ir karių bendradarbiavimo kultūra ir tradicija.

Pagrindinis nacionalinio saugumo politikos tikslas - valstybės ir kiekvieno piliečio jègomis saugoti demokratines šalies vertybes, jas plètoti, užtikrinti saugų tautos būvị tiek išoreje, tiek viduje, vykdyti atgrasymo veiksmus nuo potencialių priešų, ginti Lietuvos nepriklausomybę, jos konstitucinę santvarką ir teritorini vientisumą. Lietuvos Respublikos nacionalinio saugumo pagrindų įstatyme (1996) (toliau - Nacionalinio saugumo pagrindu ịstatymas) teigiama, kad nepriklausoma demokratinè Lietuvos valstybė privalo užtikrinti saugų Tautos gyvavimą, jos savitą ir laisvą raidą. Sukurta efektyvi nacionalinio saugumo sistema yra Tautos siekių ir demokratinès raidos užtikrinimo garantas. Vadinasi, Lietuva privalo turèti nacionalinio saugumo sistemą saugiam šalies būviui užtikrinti.

Lietuvos teisiniai gynybos pagrindai yra grindžiami Lietuvos Respublikos Konstitucija (1992) (toliau - LR Konstitucija), ịstatymais ir kitais nacionalinès ir tarptautiniais teisès aktais, prie kurių Lietuva yra prisijungusi arba juos ratifikavusi. Sprendimus dèl karo padèties ịvedimo, mobilizacijos, dèl Lietuvos karinių vienetu dalyvavimo tarptautinèse operacijose priima Lietuvos Respublikos Prezidentas ir Seimas pagal Konstituciją ir priimtus teisès aktus. Taigi, Lietuva, kaip ir kitos NATO šalys, konflikto ir (ar) krizių metu vykdydama karių ir civilių bendradarbiavimą, taip pat gali remtis bendromis NATO CIMIC doktrinos gairemis, jos teikiamais metodais ir priemonėmis tam, kad karių ir civilių ryšys būtų paprasčiau koordinuojamas, aiškus, teiktų abipusę naudą.

Vadovaujantis LR Konstitucijos (1992) 3 straipsniu, „Tauta ir kiekvienas pilietis turi teisę priešintis bet kam, kas prievarta kèsinasi i Lietuvos valstybès nepriklausomybę, teritorijos vientisuma, konstitucinę santvarka“. Taip pat LR Konstitucijos 139 straipsnis nurodo, kad „Lietuvos valstybès gynimas nuo užsienio ginkluoto užpuolimo - kiekvieno Lietuvos Respublikos piliečio teisè ir pareiga “. Pagal Lietuvos Respublikos nacionalinio saugumo pagrindų įstatymą, „kariuomenė yra viena iš Lietuvos nacionalinị saugumą užtikrinančių subjektų. Demokratinė ir nepriklausoma Lietuvos valstybė privalo užtikrinti saugų Tautos būvị, jos laisvą raidą, taip pat sukurti veiksmingą nacionalinio saugumo sistemą, kuri yra pagrindinis „demokratinès raidos užtikrinimo garantas“. Aukščiausias nacionalinio saugumo politikos tikslas yra sutelktomis piliečiu ir valstybès jègomis stiprinti nacionalinị saugumą, Tautos saugų būvị, atgrasyti kiekvieną galimą agresorių. Tai reiškia, kad prie šalies saugumo politikos kūrimo ir jos užtikrinimo prisideda kiekvienas Lietuvos pilietis, nesvarbu, karys jis ar civilis, kadangi Lietuvos nacionalinio saugumo sistema remiasi pilietine visuomene, suvokiančia galimas grèsmes, pavojus 
ir prisiimančia atsakomybę, šalies institucijų veikla ir kiekvieno Lietuvos piliečio dalyvavimu. Kadangi Lietuva priklauso Europos Sajungai (toliau - ES) ir Šiaurès Atlanto sutarties organizacijai (angl. North Atlantic Treaty Organization, toliau NATO), taip pat yra jų bendro saugumo ir gynybos dalis. Taip pat Lietuvos nacionalinio saugumo politiką sudaro socialinės, kultūros, ekonomikos, aplinkos apsaugos, mokslo ir švietimo ir kitos valstybès politikos nuostatos. Todèl šalies saugumas yra integralus procesas, ị kurị itraukiama visuomenè ir valstybès institucijos, pvz., kariuomenè. Piliečiai, kad užtikrintų nacionalinị saugumą, turi:

- saugoti tautines vertybes ir ugdyti pasiryžimą ginti Lietuvos laisvę;

- rengtis visuotiniam pilietiniam pasipriešinimui;

- plètoti visuomenès institutus, taip pat piliečių draugijų / susivienijimų veiklą.

Pagal LR krašto apsaugos ministro 2015 m. rugpjūčio 19 d. ịsakymu Nr. V-849 patvirtintą Lietuvos Respublikos piliečių rengimo valstybės gynybai strategiją, šalyje veikiančiomis karinio rengimo formomis bus užtikrintas reikiamo skaičiaus parengtų piliečių, kurie bus pasiruošę ginti valstybę, parengimas. Šia strategija siekiama, kad karinis rengimas ir krašto gynyba nebūtų suvokiama tik kaip ginkluotujų pajègų veikla ir pati krašto gynyba būtų suvokiama plačiau nei tik ginkluota gynyba nuo agresoriaus. Dabartiniu metu pavojų kelia ne tik konvencinio karo galimybè, bet ir nekonvencinès grèsmès, kurios kyla kibernetiniam saugumui, informacinei erdvei ir t. t. Dẻl šios priežasties, pagal Lietuvos krašto apsaugos ministro 2015 m. LR piliečių rengimo valstybès gynybai strategiją, svarbus piliečiu ugdymas ir pasitikèjimo kariuomene didinimas naudojant ir šiuolaikines technologijas bei ,isileidžiant civilius ị kariuomenę“.

\section{Tyrimo metodologija}

Empirinio tyrimo objektas - Kunigaikščio Vaidoto mechanizuotojo pėstininkų bataliono (toliau - VMPB) karių ir civilių bendradarbiavimo priemonès.

Empirinio tyrimo tikslas - ištirti Kunigaikščio Vaidoto mechanizuotajame pėstininkų batalione naudojamas karių ir civilių bendradarbiavimo priemones ir jų veiksmingumą.

Tyrimo uždaviniai: 1) nustatyti karių ir civilių bendradarbiavimo svarbą Lietuvos valstybei; 2) ištirti tyrimo dalyviu požiūrị i l VMPB taikomas karių ir civilių bendradarbiavimo priemones ir 3) ištirti informantų požiūrị i VMPB taikomų karių ir civilių bendradarbiavimo priemonių veiksmingumą.

Siekiant išsiaiškinti karių ir civilių bendradarbiavimo VMPB būklę, $2019 \mathrm{~m}$. rudenị buvo atliktas kokybinis tyrimas (interviu). Tyrimo instrumentą sudare keli klausimai, ị kuriuos gavus atsakymus buvo siekiama sužinoti informantų nuomonę apie karių ir civilių bendradarbiavimo svarbą Lietuvos valstybei; požiūrị i taikomas karių ir civilių bendradarbiavimo priemones bei jų veiksmingumą.

Tyrimo dalyvių (informantų) atrankos kriterijai: 1) ekspertu: tiesiogiai dirba arba yra dirbę karių ir civilių bendradarbiavimo klausimais VMPB; Lietuvos 
kariuomeneje tarnauja ne mažiau kaip 2 metus; VMPB tarnauja ne mažiau kaip 1 metus; 2) VMPB PKT: Lietuvos kariuomenèje tarnauja ne mažiau kaip 2 metus; VMPB tarnauja ne mažiau kaip 1 metus; 3 ) civilių: vykdo arba yra vykdę bendradarbiavimą su VMPB; bendradarbiavo su VMPB ne seniau kaip prieš 2 metus.

Civilių tyrimo dalyvių atranka buvo vykdoma „sniego gniūžtès principu“, atlikus interviu su ekspertais (Gaižauskaitè ir kt., 2016, p. 15).

Kokybinio tyrimo imtis - interviu buvo atliekamas tol, kol buvo pasiektas „prisotinimo“" efektas (Gaižauskaitė ir kt., 2016, p. 18), t. y. informantų atsakymai pradejo kartotis. Šis efektas, atliekant tyrimą, su ekspertais pasireiškè apklausus 5 žmones, vykdant VMPB PKT karių tyrimą - apklausus 4 žmones, o tiriant civilius apklausus 4 asmenis.

Visi dalyvavę tyrime asmenys buvo užkoduoti ir suskirstyti ị grupes: pirmoji grupé - ekspertai (E1, E2, E3, E4, E5), antroji grupé - VMPB PKT kariai (K1, K2, $\mathrm{K} 3, \mathrm{~K} 4)$, trečioji grupè - civiliai asmenys $(\mathrm{C} 1, \mathrm{C} 2, \mathrm{C} 3, \mathrm{C} 4)$.

\section{Tyrimo rezultatai}

\section{Informantu nuomonè apie kariu ir civiliu bendradarbiavimo svarba Lietuvos valstybei}

Remiantis tyrimo dalyviu ekspertu atsakymais, kategorija „Kariu ir civiliu bendradarbiavimo svarba Lietuvos valstybei “ buvo suskirstyta ị dvi subkategorijas (žr. 1 lentelę).

1 lentelè. Karių ir civilių bendradarbiavimo svarba Lietuvos valstybei (ekspertų nuomonė)

\begin{tabular}{|c|c|c|}
\hline Kategorija & Subkategorija & Patvirtinantis teiginys \\
\hline \multirow{2}{*}{$\begin{array}{l}\text { Karių ir civiliu } \\
\text { bendradarbiavimo } \\
\text { svarba Lietuvos } \\
\text { valstybei }\end{array}$} & $\begin{array}{c}\text { Visuomenès parama } \\
\text { Lietuvos kariuomenei }\end{array}$ & $\begin{array}{l}\text { „Kariu ir civiliu bendradarbiavimas stiprina } \\
\text { visuomenés pasitikejima Lietuvos kariuomene“(E4) }\end{array}$ \\
\hline & $\begin{array}{l}\text { Civiliai - sudedamoji } \\
\text { gynybos dalis }\end{array}$ & $\begin{array}{l}\text { „Mūsu kariuomené yra viena maža gynybos } \\
\text { sudètiné dalis < ...> (E4) }\end{array}$ \\
\hline
\end{tabular}

Atlikus rezultatų (žr. 1 lentelę) analizę paaiškèjo, kad visi informantai ekspertai atsakè, jog karių ir civilių bendradarbiavimas svarbus kuriant visuomenès pasitikèjimą karine šalies struktūra, kad būtų užtikrinta nekarinių veikèjų parama galimo konflikto atveju. Be to, civilių palaikymas, pasak informanto (E2), labai svarbus, kad šie suprastų kariuomenès funkciją ir kam skiriamos lèšos krašto apsaugai: ,,jeigu visuomene galvoja, kad kariuomene yra nereikalinga, tai, kaip sakant, tada prasidès visokie pykčiai, kodèl mes skiriame jiems čia tuos pinigus, kam čia reikalinga “. Pasak kito informanto (E5), be lojalaus ir bendro tikslo siekiančio civilio negalima pasiekti šimtaprocentinio rezultato krašto gynyboje, nes ne paslaptis, kad ir priešiškai nusiteikusios valstybės institucijos užsiima Lietuvos visuomenès nuomonès formavimu: „<...> tik laiko klausimas, kas greičiau palenks civili i savo pusę, o 
to mūsu moko skaudi Lietuvos Respublikos praeitis “. Dar vienas informantas (E4) išskyrè kitą priežastị, kodèl karių ir civilių bendradarbiavimas yra svarbus. Jis teigè, jog „Lietuvos gynyba yra ne tik kariuomenés reikalas, tai yra visos valstybès reikalas $<\ldots>$ " (E4), o tai reiškia, kad civiliai yra sudedamoji krašto apsaugos dalis. Taigi, anot ekspertų, pagrindinè priežastis, kodèl karių ir civilių bendradarbiavimas svarbus Lietuvos valstybei, yra ta, kad bendradarbiavimas kuria civilių pasitikèjimą Lietuvos kariuomene, o nuo to priklauso galimo karo eiga ir galutinis rezultatas.

Remiantis kariu atsakymais, kategorija „Kariu ir civiliu bendradarbiavimo svarba Lietuvos valstybei " buvo suskaidyta ị dvi subkategorijas (žr. 2 lentelę).

2 lentelè. Karių ir civilių bendradarbiavimo svarba Lietuvos valstybei (karių nuomonė)

\begin{tabular}{|c|c|c|}
\hline Kategorija & Subkategorija & Patvirtinantis teiginys \\
\hline \multirow[t]{2}{*}{$\begin{array}{l}\text { Kariụ ir civiliụ } \\
\text { bendradarbiavimo } \\
\text { svarba Lietuvos } \\
\text { valstybei }\end{array}$} & $\begin{array}{l}\text { Civilių parama } \\
\text { Lietuvos } \\
\text { kariuomenei }\end{array}$ & $\begin{array}{l}\quad,<\ldots>\text { be visuomenès paramos, šalies apginti } \\
\text { nepavyks" (K2) } \\
\text {,<..>>civiliai konflikto atveju gali labai stipriai } \\
\text { prisideti prie šalies gynybos" (K3) }\end{array}$ \\
\hline & $\begin{array}{l}\text { Visuomenès } \\
\text { rengimas valstybès } \\
\text { gynybai }\end{array}$ & $\begin{array}{l},<\ldots>\text { visuomenès rengimas savo valstybès gynybai } \\
\text { yra vienas iš svarbiausiu uždavinių" (K2) }\end{array}$ \\
\hline
\end{tabular}

Atlikus tyrimo rezultatu analizę, informantai (K1, K2, K3, K4) teigè, kad karių ir civilių bendradarbiavimas svarbus Lietuvos valstybei, kadangi be civilių paramos krašto gynyba neimanoma ir nuo to priklauso „,karo scenarijus “ (K1). O pati parama gali būti labai įvairi: žvalgybos informacija, maistas, apgyvendinimas (K1). Visi šie veiksniai „daro didele ịtaka tikro karo scenarijui“ (K1). Apibendrinant galima teigti, kad visi informantai kariai patvirtino, jog be civiliu palaikymo valstybės apginti nepavyks, ,, nes esam viena tauta “ (K3), taip pat karių ir civilių bendradarbiavimas - viena iš priemonių civilinès bendruomenès rengimui krašto gynybai užtikrinti.

Remiantis civiliu informantų atsakymais, kategorijoje „Kariu ir civiliu bendradarbiavimo svarba Lietuvos valstybei " buvo išskirtos dvi subkategorijos (žr. 3 lentelę).

3 lentelè. Karių ir civilių bendradarbiavimo svarba Lietuvos valstybei (civilių nuomonè)

\begin{tabular}{|c|c|c|}
\hline Kategorija & Subkategorija & Patvirtinantis teiginys \\
\hline $\begin{array}{c}\text { Karių ir civilių } \\
\text { bendradarbiavimo svarba } \\
\text { Lietuvos valstybei }\end{array}$ & $\begin{array}{l}\text { Civiliai - } \\
\text { sudedamoji } \\
\text { šalies gynybos } \\
\text { dalis }\end{array}$ & $\begin{array}{l}\text { „, }<\text {... }>\text { bendrumo jausmas siekiant tikslu ginti } \\
\text { Tévynę" (C3) } \\
\text { „Siandien kariuomenè yra neatskiriama šalies } \\
\text { pilietinès visuomenès dalis“ (C4) }\end{array}$ \\
\hline & $\begin{array}{l}\text { Civilių } \\
\text { supažindinimas } \\
\text { su kariuomene }\end{array}$ & $\begin{array}{l}\text {,<..> parodyti, kad jaunimas nebijotu } \\
\text { eiti i kariuomene“ (C2) } \\
\text { „<...> šeima turi žinoti, kur tarnaus ju vaikai“ (C3) }\end{array}$ \\
\hline
\end{tabular}


Pasak informantų, civilių supažindinimas su kariuomene yra labai svarbus dèl daugybès priežasčių: reikia ,parodyti, kad jaunimas nebijotu eiti ị kariuomene, jog kariuomené nebera patyčiu vieta, kaip buvo anksčiau, o tai civilizuota organizacija "(C2). Kitas informantas (C3) teigè, kad valstybès gynyba nèra tik kariuomenès reikalas, tai bendras visuomenès tikslas. Apibendrinant galima teigti, kad informantai išskyrė karių ir civilių bendradarbiavimo svarbą ir pabrèžè, kad visuomenę būtina supažindinti su kariuomene, nes valstybės gynyba - visų reikalas.

Apibendrinus visų trijų tyrimo dalyvių grupių nuomonę apie karių ir civilių bendradarbiavimo svarbą Lietuvos valstybei, buvo nustatyta, kad: 1) ekspertų nuomone, svarbiausia yra tai, jog minètas bendradarbiavimas kuria civilių pasitikejjimą Lietuvos kariuomene, nuo kurio priklauso galimo karo eiga ir galutinis rezultatas; 2) karių požiūriu, be civilių palaikymo, valstybès apginti nepavyks ir 3) civiliu įsitikinimu, visuomenè turi būti supažindinama su kariuomene, nes valstybès gynyba - visų reikalas. Kitaip tariant, visų grupių ekspertai vieningai pripažįsta karių ir civilių bendradarbiavimo svarbą užtikrinat Lietuvos saugumą.

\section{Informantu nuomonè apie kariu ir civiliu bendradarbiavimo priemones, taikomas VMPB}

Remiantis tyrimo dalyviu ekspertu atsakymais, kategorija „Kariu ir civiliu bendradarbiavimo priemonès, taikomos $V M P B$ “ buvo suskaidyta ị šešias subkategorijas (žr. 4 lentelę).

4 lentelè. Karių ir civilių bendradarbiavimo priemonès VMPB (ekspertų nuomonè)

\begin{tabular}{|c|c|c|}
\hline Kategorija & Subkategorija & Patvirtinantis teiginys \\
\hline \multirow{6}{*}{$\begin{array}{c}\text { Karių ir } \\
\text { civilių bendra- } \\
\text { darbiavimo } \\
\text { priemonès, } \\
\text { taikomos VMPB }\end{array}$} & $\begin{array}{l}\text { Tarpinstitucinis } \\
\text { bendradar- } \\
\text { biavimas }\end{array}$ & $\begin{array}{l},<\ldots>\text { kiekviena }<\ldots>\text { kuopa turëjo paskirta atsakomybès } \\
\text { rajonq. }<\ldots>\text { seniūnija, kurioje turejo toki standarta }- \\
\text { vienakart per ménesi padaryti gerq darba" }(\text { E1) }\end{array}$ \\
\hline & $\begin{array}{l}\text { Renginiai/ } \\
\text { (šventès, } \\
\text { koncertai ir kt.) }\end{array}$ &,$<\ldots>$ ivairios šventès, koncertai surengti“ (E1) \\
\hline & Ekskursijos & 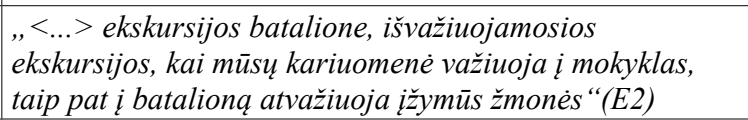 \\
\hline & $\begin{array}{c}\text { Paskaitos / } \\
\text { šviečiamoji veikla }\end{array}$ & $\begin{array}{l}\text { „, <..> keliauja po mokyklas, šviečia jaunima kariniais } \\
\text { klausimais“"(E5) }\end{array}$ \\
\hline & $\begin{array}{l}\text { Labdaringa } \\
\text { veikla }\end{array}$ & $\begin{array}{l}\text {,<...> kiekvienais metais kalediniu laikotarpiu rengiam } \\
\text { labdaros koncerta“"(E3) }\end{array}$ \\
\hline & Socialiniai tinklai & , <...> „Facebook“ ir kiti socialiniai tinklai svarbu...“ \\
\hline
\end{tabular}


Atlikus tyrimo rezultatų analizę paaiškejjo, kad, ekspertų nuomone, VMPB taiko įvairias karių ir civilių bendradarbiavimo priemones. Trys apklausti ekspertai (E1, E3, E5) iš penkių ịvardijo tarpinstitucinị bendradarbiavimą, kadangi kiekviena VMPB kuopa turi priskirtą savo atsakomybės rajoną - seniūniją, kurioje daro gerus darbus, t. y. padeda vietinei bendruomenei tvarkyti aplinką ar kapus ir kt. Du (E1, E5) iš penkių apklaustų informantų teigè, jog kita VMPB taikoma bendradarbiavimo priemonè yra vieši renginiai ar parodos, kurių metu kariai reprezentuoja Lietuvos kariuomenę, dalyvauja valstybinių švenčių minèjimuose (E5). Visi ekspertai ekskursijas ịvardijo kaip karių ir civilių bendradarbiavimo priemonę ir paminèjo ịvairias ekskursijas, pavyzdžiui, batalione, išvažiuojamąsias $\mathfrak{i}$ ịvairias mokyklas ar kitas ịstaigas. Pasak informanto, ekskursijos, ,pakvietimas visuomenès narius atvykt ị kariuomenę ir pažiūrèt, ką ta kariuomenè daro <...> apylinkių seniūnijos, bendruomenès buvo atvykusios pas mus ir mes važiavom pas juos, ir ị Kaišiadoris, ir ị Jonavą, ir ị Ukmergę" (E1). İ ekskursijas Vaidoto batalione kviečiami įvairūs žmonès: ,,mes kviečiam nuo mokyklu, nuo mažu mokiniu iki suaugusiu, iki ịvairiu vyriausybiniu ir nevyriausybiniu organizaciju atstovus, juos supažindinam su saugumo politika, leidžiam pasijusti kariais “ (E4). Batalionas užsiima ir šviečiamaja veikla, pavyzdžiui, vykstama ị ịvairias mokyklas ar institucijas, kur pristatoma Lietuvos kariuomenè. Be to, batalione NPPKT ir PKT kariams organizuojamos paskaitos, kurių metu garsūs Lietuvoje žmonès dalijasi savo sėkmès istorijomis, patirtimi, taip pat padèkoja kariams už tarnybą ir ,,saugu užnugarị “. Svarbu, jog atvykę žmonès, tikslinè auditorija, yra supažindinami patys su Lietuvos kariuomene, todèl išvykę už karinès teritorijos ribų gali skleisti žinutę apie šalies ginkluotąsias pajėgas likusiai visuomenès daliai (E4). Taip pat vienas informantų paminèjo, kad Vaidoto batalionas puikiai išnaudoja ir socialinius tinklus, tokius kaip „Facebook“, tam, kad informuotų visuomenę apie savo veiklą, užduotis ir siekius. Batalionas taip pat padeda ir jautrioms socialinèms grupėms, užsiima labdaringa veikla: „kiekvienais metais kalédiniu laikotarpiu vykdom labdaros koncerta, kurio metu surinktos lëšos irgi bütent yra skirtos padèti nepasiturinčioms šeimoms " (E3). Taigi, ekspertai išskyrè tokias karių ir civilių bendradarbiavimo priemones kaip tarpinstitucinis bendradarbiavimas, renginiai (parodos, šventès, koncertai ir kt.), ekskursijos, paskaitos / šviečiamoji ir labdaringa veikla bei socialiniai tinklai.

Remiantis tyrimo dalyviu kariu atsakymais, kategorija ,, Kariu ir civiliu bendradarbiavimo priemonès, taikomos VMPB " buvo suskirstyta ị penkias subkategorijas (žr. 5 lentelę). 


\section{5 lentelè. Karių ir civilių bendradarbiavimo priemonès VMPB}

(karių nuomonè)

\begin{tabular}{|c|c|c|}
\hline Kategorija & Subkategorija & Patvirtinantis teiginys \\
\hline \multirow{5}{*}{$\begin{array}{c}\text { Kariụ ir civiliụ } \\
\text { bendradarbiavimo } \\
\text { priemonès, } \\
\text { taikomos VMPB }\end{array}$} & Ekskursijos & $\begin{array}{l},,<\ldots>\text { pagrindinis turbūt ekskursijos“ }(K 1) \\
, \text { Ekskursijos“ }(K 3)\end{array}$ \\
\hline & $\begin{array}{l}\text { Paskaitos / } \\
\text { šviečiamoji } \\
\text { veikla }\end{array}$ & $\begin{array}{l},,<\ldots>\text { verslo lyderiai ateina, dèsto savo paskaitas“ }(K 1) \\
,<\ldots>\text { kviečiami garsūs žmonès “ }(K 3)\end{array}$ \\
\hline & $\begin{array}{l}\text { Socialiniai } \\
\text { tinklai }\end{array}$ & $\begin{array}{l}\text {, }<\ldots>\text { pirma karta turbūt matau, kad taip } \\
\text { socialiniai tinklai būtu išnaudojami“"(K1) } \\
<\ldots>\text { socialiniai tinklai“"(K3) } \\
,<\ldots>\text { socialmedija“"(K4) }\end{array}$ \\
\hline & $\begin{array}{l}\text { Tarpinstitucinis } \\
\text { bendradar- } \\
\text { biavimas }\end{array}$ & $\begin{array}{l}\text { „Kuopoms yra duoti atsakomybès rajonai, kuriuose } \\
\text { užmezgami ryšiai su seniūnijomis “ (K2) } \\
<. \text { > pagalba seniūnijai" (K3) }\end{array}$ \\
\hline & Renginiai & $\begin{array}{l},<\ldots>\text { organizuoja bendrus renginius“ }(K 3) \\
, \text { Renginiai“ }(K 4)\end{array}$ \\
\hline
\end{tabular}

Atlikus tyrimo rezultatų analizę paaiškèjo, kad pagrindinès karių ir civilių bendradarbiavimo priemonès Vaidoto batalione yra ekskursijos (K, K3), paskaitos / šviečiamoji veikla (K1, K3), socialiniai tinklai (K1, K3, K4), tarpinstitucinis bendradarbiavimas $(\mathrm{K} 2, \mathrm{~K} 3)$ ir bendri renginiai $(\mathrm{K} 3, \mathrm{~K} 4)$. Ekskursijų metu batalione civiliai supažindinami su Lietuvos kariuomene, jos funkcijomis, užduotimis, naudojama ginkluote, ekipuote ir technika, ,paprasčiausiai netgi, kokia šauktiniu rutina, kokia kitu kariu rutina“ (K1). Kadangi ,,ateina žmonès ir apčiupinejja, pasižiūri, kaip ginklai veikia, ka mes turim, vizualiai ir fiziškai pasižiūri“ (K1). Tarpinstitucinis bendradarbiavimas vyksta su rajono savivaldybe bei seniūnijomis, kadangi kariai „,talkina tvarkant seniūniju lankytinas vietas “ (K2). Pagal VMPB vado 2018 m. įsakymą Nr. V-296 VMPB plètoja sąveiką su LR savivaldybèmis ir kitomis civilinès valdžios institucijomis tam, kad konflikto atveju būtu užtikrintas visuomenès palaikymas. Be to, kariai prisideda prie savivaldybių kraštovaizdžio gerinimo, aplinkotvarkos, prireikus paruošia atsakomybės rajonus gynybai. Pagal minètą įsakymą kiekviena VMPB kuopa turi ne rečiau kaip vieną kartą per mènesi lankytis numatytuose atsakomybės rajonuose: I mechanizuotajai pėstininkų kuopai (toliau - MPK) - Veprių seniūnija; II MPK - Žiežmarių seniūnija; III MPK Kaišiadorių rajono savivaldybė; IV MPK - Žaslių seniūnija; Sunkiosios ginkluotès kuopai - Upininkų seniūnija; Štabo kuopai - Palomenès seniūnija. Taigi, kariai informantai išskiria įvairiausias karių ir civilių bendradarbiavimo priemones: ekskursijas, paskaitas / šviečiamają veiklą, socialinius tinklus, tarpinstitucinị bendradarbiavimą ir bendrus renginius.

Remiantis tyrimo dalyvių civilių atsakymais, kategorija „Karių ir civilių bendradarbiavimo priemonès, taikomos VMPB“ buvo suskirstyta ị penkias subkategorijas (žr. 6 lentelę). 
6 lentelè. Karių ir civilių bendradarbiavimo priemonès, taikomos VMPB (civilių nuomonè)

\begin{tabular}{|c|c|c|}
\hline Kategorija & Subkategorija & Patvirtinantis teiginys \\
\hline \multirow[t]{6}{*}{$\begin{array}{c}\text { Karių ir civilių } \\
\text { bendradarbiavimo } \\
\text { priemonès, } \\
\text { taikomos VMPB }\end{array}$} & $\begin{array}{c}\text { Tarpinstitucinis } \\
\text { bendradarbiavimas }\end{array}$ & $\begin{array}{l}\text { „Kariai }<\ldots>\text { rengia karines pratybas, dalyvauja } \\
\text { savivaldybès organizuojamuose renginiuose, } \\
\text { bendradarbiauja su Lietuvos šauliu sajungos } \\
\text { Karaliaus Mindaugo 10-osios rinktinès Ukmergès } \\
\text { 1002-aja šauliu kuopa“ (C4) }\end{array}$ \\
\hline & $\begin{array}{l}\text { Renginiai / } \\
\text { parodos }\end{array}$ & 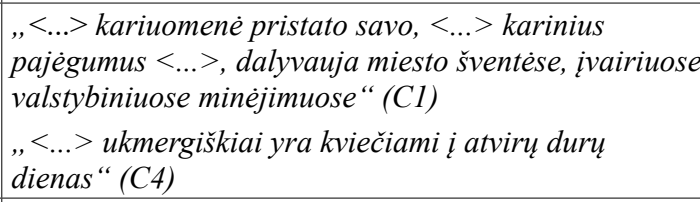 \\
\hline & Paskaitos & $\begin{array}{l}\text { „<...> Vaidoto batalione vedžiau motyvacinę paskaita } \\
\text { šauktiniams kariams" (C2) }\end{array}$ \\
\hline & Ekskursijos & $\begin{array}{l}\text {, }<\ldots>\text { ekskursijos “(C3) } \\
,<\ldots>\text { rengiamos ekskursijos batalione“ }(C 4)\end{array}$ \\
\hline & Žygiai & „, $<\ldots>$ pessčiujų žygiai“"(C3) \\
\hline & $\begin{array}{l}\text { Konferencijos / } \\
\text { konkursai }\end{array}$ & ,,<..> konferencijos, konkursai“"(C3) \\
\hline
\end{tabular}

Pasak civilio informanto, karių ir civilių bendradarbiavimas vyksta ,naujom formom ir vis atviriau " (C1). Kaip vieną bendradarbiavimo priemonių informantas (C1) ìvardijo tarpinstitucini bendradarbiavimą: ,, apie Vaidoto bataliona $<\ldots>$ jis prisideda prie Upininku seniūnijos renginiu organizavimo " (C1), taip pat renginius, parodas, kuriu metu yra reprezentuojama Lietuvos kariuomenè ar tam tikri jos vienetai, parodoma naudojama ginkluote ir technika, minimos valstybinès šventès ,valstybiniuose minèjimuose, ar tai bütu Sausio 13-oji, Kovo 11-oji, Vasario 16-oji“ (C1). Vienas informantas (C3) taip pat išskyrè ir tokias bendradarbiavimo priemones kaip ekskursijos, pesčiujų žygiai ar organizuojamos bendros konferencijos, konkursai. Taigi, civiliai informantai išvardijo įvairias karių ir civilių bendradarbiavimo priemones VMPB, tiek šviečiamają (paskaitas, konferencijas), tiek aktyvią (renginius, parodas, žygius, ekskursijas ir kt.) veiklą.

Apibendrinus visų trijų grupių tyrimo dalyvių nuomonę apie karių ir civilių bendradarbiavimo priemonių taikymą VMPB, buvo nustatyta, kad: 1) visų grupių atstovų nuomonè sutampa, jog VMPB yra taikomos šios priemonès: renginiai (parodos, šventès, koncertai ir kt.), ekskursijos, paskaitos / šviečiamoji veikla ir socialiniai tinklai; 2) kariai ir ekspertai mano, kad vyksta ir tarpinstitucinis bendradarbiavimas; 3) ekspertai išskyrè dar ir labdaringą veiklą. 
Informantu nuomone apie kariu ir civiliy bendradarbiavimo veiksmingiausias priemones, taikomas VMPB

Remiantis ekspertu atsakymais, kategorija „Veiksmingiausios / geriausios taikytos priemonès kuriant ryšius su civiliais VMPB " buvo suskirstyta ị tris subkategorijas (žr. 7 lentelę).

7 lentelè. Veiksmingiausios / geriausios taikytos priemonès kuriant ryšius su civiliais VMPB (ekspertų nuomonè)

\begin{tabular}{|c|c|c|}
\hline Kategorija & $\begin{array}{c}\text { Sub- } \\
\text { kategorija }\end{array}$ & Patvirtinantis teiginys \\
\hline \multirow{3}{*}{$\begin{array}{l}\text { Veiksmingiausios/ } \\
\text { geriausios taikytos } \\
\text { priemonės kuriant } \\
\text { ryšius su civiliais } \\
\text { VMPB }\end{array}$} & Švietimas & $\begin{array}{l},<\ldots>\text { bendrai paaiškinamos kariuomenès funkcijos, kad } \\
\text { kariuomené yra Lietuvos taikos saugotoja ir gyneja, ne } \\
\text { karo, kaip tradiciškai“"(E1) }\end{array}$ \\
\hline & $\begin{array}{l}\text { Labdaringa } \\
\text { veikla }\end{array}$ & $\begin{array}{l}\text { „,..> visos labdaringos akcijos, kur VMPB rodo demesi } \\
\text { civiliams, yra labai naudingos ir veiksmingos" (E5) }\end{array}$ \\
\hline & Ekskursijos & $\begin{array}{l}\text { „Veiksmingiausios yra ekskursijos, bet kokiu atveju“ (E2) } \\
\text { „Viena iš veiksmingiausiu, manau, yra ekskursijos“ (E3) } \\
\text { „Mano minètos ekskursijos“ (E4) }\end{array}$ \\
\hline
\end{tabular}

Atlikus tyrimo rezultatų analizę, buvo išskirtos keturios veiksmingiausios / geriausios karių ir civilių bendradarbiavimo priemonès VMPB: visuomenès švietimas, labdaringa veikla, socialiniai tinklai ir ekskursijos. Ekskursijos, pasak informantų (E2, E3, E4), yra viena veiksmingiausių priemonių: , , $<>$ kai žmogus atvažiuoja pats i ekskursija, $i$ Vaidoto bataliona, pamato, koks yra vidus kariuomenès, kaip tie kariai gyvena, kokia ta pati technika, ginkluote, ir jiems tiesiog pasidaro kažkaip saugiau, kaip sakant, akmuo nuo širdies nusirita" (E3). Taip pat ekspertas (E3) neslepia, jog buvo žmonių, kurie po ekskursijų batalione sako, jog tikrai taip negalvojo iki tol ir dabar jiems ramiau dèl savo šalies saugumo (E3). Dar vienas svarbus aspektas, jog, rengdami ekskursijas ir supažindindami civilius su kariais, ,,mes turim galimybe paneigti visus mitus" (E4), ,, atvykę vaikai papasakos savo tèvams, kad kariuomene nèra tas baisus dalykas, kur sovietu laikais buvo baudžiami, išnaudojami, mušami kariai, o tai yra puiki mokykla jaunimui “ (E5). Kaip veiksmingą karių ir civilių bendradarbiavimo priemonę ekspertai (E2 ir E7) išskyrė švietimą apie Lietuvos kariuomenę, jos funkciją ir labdaringą veiklą, kurios metu suteikiama pagalba jautrioms socialinèms grupèms. Taigi, ekspertai kaip veiksmingiausias karių ir civilių bendradarbiavimo priemones išskyre švietimą, labdaringą veiklą ir ekskursijas.

Remiantis kariu atsakymais, kategorija ,,Veiksmingiausios / geriausios taikytos priemonès kuriant ryšius su civiliais VMPB" buvo suskaidyta ị keturias subkategorijas (žr. 8 lentelę). 
8 lentelè. Veiksmingiausios / geriausios taikytos priemonès

kuriant ryšius su civiliais VMPB (karių nuomonè)

\begin{tabular}{|c|c|c|}
\hline Kategorija & Subkategorija & Patvirtinantis teiginys \\
\hline \multirow{4}{*}{$\begin{array}{l}\text { Veiksmingiausios / geriausios } \\
\text { taikytos priemonès kuriant } \\
\text { ryšius su civiliais VMPB }\end{array}$} & Renginiai & $\begin{array}{l}\text { "Daug žymiu žmoniu atvyko, pamatè, kaip atrodo } \\
\text { ne tik VMPB, bet ir kariuomene“ (K4) }\end{array}$ \\
\hline & $\begin{array}{l}\text { Socialiniai } \\
\text { tinklai }\end{array}$ & $\begin{array}{l}\text { „<...> socialiniai tinklai bus, turime tikrai ne } \\
\text { viena gera susukta klipuka, aš dar karta žiūriu ir } \\
\text { norisi iš naujo stot } i \text { kariuomene “ (K1) }\end{array}$ \\
\hline & Ekskursijos & $\begin{array}{l}\text { „Veiksmingiausios }<\ldots>\text { tradicinès, galbūt } \\
\text { ekskursijos“ (K1) } \\
\text { „,kai civiliai atvyksta i VMPB“ (K2) }\end{array}$ \\
\hline & Parodos & $\begin{array}{l}\text { „Organizuojant parodas apie ginklus bei } \\
\text { techniką“(K3) }\end{array}$ \\
\hline
\end{tabular}

Pagal gautus rezultatus, informantai (K1, K2, K3, K4) kaip veiksmingiausias / geriausias priemones, kuriant ryšius su civiline bendruomene, išskyrẻ socialinius tinklus (K1), ekskursijas (K1, K2), parodas (K3) ir renginius (K4). Taigi, kariai informantai kaip veiksmingiausias / geriausias karių ir civilių bendradarbiavimo priemones išskyrè renginius, socialinius tinklus, ekskursijas ir parodas.

Remiantis civiliu atsakymais, kategorija „Veiksmingiausios / geriausios taikytos priemonès kuriant ryšius su civiliais $V M P B$ " buvo suskaidyta i penkias subkategorijas (žr. 9 lentelę).

9 lentelè. Veiksmingiausios / geriausios taikytos priemonès kuriant ryšius su civiliais VMPB (civilių nuomonè)

\begin{tabular}{|c|c|c|}
\hline Kategorija & Subkategorija & Patvirtinantis teiginys \\
\hline \multirow[t]{5}{*}{$\begin{array}{l}\text { Veiksmingiausios / } \\
\text { geriausios taikytos } \\
\text { priemonès kuriant } \\
\text { ryšius su civiliais } \\
\text { VMPB }\end{array}$} & Parodos & 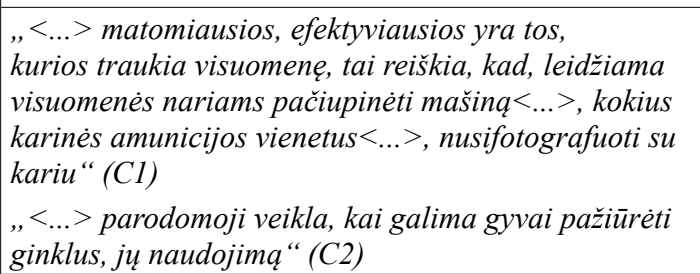 \\
\hline & Ekskursijos & $\begin{array}{l}{ }_{,<\ldots>}>\text { ekskursijos biudžetinèms bei verslo } \\
\text { organizacijoms"(C3) }\end{array}$ \\
\hline & $\begin{array}{l}\text { Bendri } \\
\text { renginiai }\end{array}$ & $\begin{array}{l}\text { Tai bendri renginiai }<\ldots>\text { ". }(C 2) \\
,<\ldots>\text { susitikimai su Lietuvoje žinomais žmonemis“ } \\
\text { (C3) }\end{array}$ \\
\hline & $\begin{array}{l}\text { Tarpinstitucinis } \\
\text { bendradar- } \\
\text { biavimas }\end{array}$ & „< $<\ldots>$ bendradarbiavimas su Kadetu licëjumi“ (C3) \\
\hline & $\begin{array}{l}\text { Socialiniai } \\
\text { tinklai }\end{array}$ & $\begin{array}{l},<\ldots>\text { aktyvus informavimas visuomenès apie batalio- } \\
\text { no veikla per socialinius tinklus" (C3) }\end{array}$ \\
\hline
\end{tabular}


Informantai $(\mathrm{C} 1, \mathrm{C} 2, \mathrm{C} 3)$ įvardijo labai įvairias, jų nuomone, veiksmingiausias / geriausias, karių ir civilių bendradarbiavimo priemones. Pavyzdžiui, informantas C3 paminejo bendradarbiavimą ne tik su savivaldybemis, bet ir kitomis institucijomis: ,, < ..> su vaiku namais, socializacijos centrais “(C3). Kalbant apie tarpinstitucinį bendradarbiavimą, kaip ịsimintiniausią ịvykị, kuriant ryšius su civiline bendruomene, informantas (C3) įvardijo - „pasirašymas bendradarbiavimo sutarties tarp Vaidoto mechanizuotojo pėstininkų bataliono ir Generolo Povilo Plechavičiaus kadetų licejjaus " (C3). Taigi, civiliai informantai ịvardijo net penkias veiksmingas karių ir civilių bendradarbiavimo priemones, taikomas VMPB: parodas, ekskursijas, bendrus renginius, tarpinstitucinị bendradarbiavimą ir socialinius tinklus.

Apibendrinant visų trijų grupių dalyvių nuomonę apie veiksmingiausias / geriausias taikomas priemones kuriant kariuomenes ryšius su civiliais VMPB, buvo nustatyta, kad 1) visų trijų grupių informantų nuomonè sutapo, jog ekskursijos yra priskiriamos veiksmingiausiu priemonių grupei; 2) informantų karių ir civilių nuomonès dažniausiai sutapo ir jų atstovai teigè, jog veiksmingiausioms priemonèms priskirtinos parodos, ekskursijos, renginiai ir socialiniai tinklai; 3) tik informantai ekspertai išskyrè švietimą ir labdaringą veiklą kaip veiksmingiausias priemones ir 4) tik civilių informantų nuomone, tarpinstitucinis bendradarbiavimas yra viena veiksmingiausių priemonių.

\section{Išvados}

- Išanalizavus mokslinę literatūrą buvo pastebėta, kad civilių ir kariuomenès santykiai ir bendradarbiavimas nagrinèjamas ịvairiais aspektais ir ši analizė remiasi skirtingomis teorijomis, pavyzdžiui, harmonijos, susiliejimo ir kitomis. Atliekant tyrimą nustatyta, kad Lietuva, kaip ir kitos NATO šalys, vadovaujasi NATO karių ir civilių bendradarbiavimo CIMIC doktrina, kuri taikoma konflikto / operacijų metu, tačiau Lietuva neturi savo nacionalinès CIMIC koncepcijos, skirtos taikos metui, todèl karių ir civilių bendradarbiavimas vyksta pasitelkus viešuosius ryšius, taikant įvairias šiems ryšiams būdingas priemones. Būtent tokiam požiūriui, t. y. karių ir civilių bendradarbiavimui naudojant viešuosius ryšius, savo darbuose nemažai dėmesio skiria užsienio šalių tyrèjai, pavyzdžiui, V. Gruber (2015), C. C. Moskos (2000), G. D. L. Jeeni ir kt. (2015). Kadangi viešieji ryšiai yra strateginès komunikacijos proceso dalis, kuri kuria naudingus santykius tarp tam tikros organizacijos ir jos auditorijos, dar $2011 \mathrm{~m}$. buvo paskelbtas krašto apsaugos ministro įsakymas „Dèl Krašto apsaugos viešujų ryšiu gairių tvirtinimo“, kuriame numatytos ne tik KAS viešujjų ryšių kryptys, apimančios komunikaciją su civiliais, bet ir jų igyvendinimo priemonès.

- Išanalizavus LR teisès aktus, reglamentuojančius karių ir civilių bendradarbiavimą, nustatyta, kad turime sèkmingai funkcionuojančią teisinę bazę, reguliuojančią visuomenès ir kariuomenès gyvenimą ir santykius, veiklas ir funkcijas. 
Taip pat pastebèta, jog gerai funkcionuojančios teisinès bazès nepakanka, norint kurti ir puoselèti civilių ir karių bendradarbiavimo kultūrą ir tradicijas, nes tik tada bus užtikrintas mūsų šalies saugumas.

- Atlikus Kunigaikščio Vaidoto mechanizuotajame pėstininkų batalione empirinị tyrimą (interviu), kuriame dalyvavo ekspertų, karių ir civilių grupès, buvo nustatyta, kad: 1) visų grupių atstovai vieningai pripažista karių ir civilių bendradarbiavimo svarbą, užtikrinat Lietuvos saugumą; 2) visų trijų grupių informantų nuomonė apie karių ir civilių bendradarbiavimo kai kurias VMPB taikomas priemones sutampa, t. y. apie renginius, ekskursijas, paskaitas / šviečiamają veiklą ir socialinius tinklus, tačiau kariai ir ekspertai papildomai išskyrè ir tarpinstitucini bendradarbiavimą, o ekspertai pažymèjo dar ir labdaringą veiklą; 3) visų informantų grupių nuomone, ekskursijos buvo pripažintos veiksmingiausia / geriausia taikoma priemone, kuriant kariuomenès ryšius su civiliais VMPB.

\section{Literatūra}

Anderson, J. M. (1998). Civil-military relations and concordance theory: a case study of Argentina. Monterey, California: Naval Postgraduate School.

Angstrom, J. (2013). The changing norms of civil and military and civilmilitary relations theory. Journal Small Wars and Insurgencies, 24, p. 224-236.

Brožič, L. (2013). Public Relations and the Military-Evaluation of the Slovenian Armed Forces. Slovenia: Ministry of Defence.

Civil-Military Cooperation Centre of Excellence (2019). CIMIC Handbook, [žiūrèta 2019-09-11]. Prieiga per internetą: https://www.cimic-coe.org/products/ conceptual-design/downloads/ccoe-publications/field-handbook/pdf

Clausewitz, C. (2008). Apie karq. Vilnius: LKA.

Forsey, C. (2018). What is Public Relations? [žiūrèta 2019-10-12]. Prieiga per internetą: https://blog.hubspot.com/marketing/public-relations-definition.

Gaižauskaitė, I., Valavičienè, N. (2016). Socialiniu tyrimų metodai: kokybinis interviu. Vadovėlis. Vilnius: MRU.

Gregory, A. (2003). Public Relations in Practice. London: The Institute of Public Relations.

Gruber, V. (2015). Civil-Military-Relations Theory: The Case of the Kurdistan Regional Government to Iraq. Small Wars Journal, 2, p. 224-236.

Heath, R. L. (2005). Encyclopedia of Public Relations. London: Sage Publications.

Hoffmann, J. (2019). Harmonious public relations: a deconstruction of U.S.based public relations textbooks. Critical Studies in Media Communication.

Hungtinton, S. (1957). Soldier and the State. Harvard: Harvard University.

Jeeni, G. D. L., Peterson, M. N., Jameson J. K., Cubbage, F. W. (2015). Military Perspectives on Public Relations Related to Environment Issues. Journal of Public Relations Research, 27 (4), p. 353-369. 
Leyda, J. W. (1972). The New Military Professional: Changing Conception of Military Professionalism in the Post War Period. Riverside: University of California.

Lietuvos Respublikos Konstitucija. Žin. 1992, Nr. 33-1014.

Lietuvos Respublikos krašto apsaugos ministro $2008 \mathrm{~m}$. vasario $19 \mathrm{~d}$. įsakymas Nr. V-142 „Dèl krašto apsaugos sistemos interneto svetainès koncepcijos “.

Lietuvos Respublikos krašto apsaugos ministro 2015 m. rugpjūčio 19 d. ịsakymas Nr. V-849 „Dél Lietuvos Respublikos piliečiu rengimo valstybès gynybai strategijos “.

Lietuvos Respublikos krašto apsaugos ministro $2011 \mathrm{~m}$. gruodžio $28 \mathrm{~d}$. ịsakymas Nr. V-146 „, Dèl Krašto apsaugos sistemos viešujų ryšiu gairiu tvirtinimo“. TAR, 2011, Nr. 11965.

Lietuvos Respublikos nacionalinio saugumo pagrindu įstatymas. Žin., 1997, Nr. 2-16.

LR krašto apsaugos ministro 2019 m. birželio 6 d. įsakymas NR. V-511 „Dèl Asociaciju ir viešuju istaigu veiklos programu dalinio finansavimo iš valstybès biudžeto asignavimu nuostatu patvirtinimo “.

Morgan, M. J. (2002). Clausewitz on civil-military relations: What Hitler should have known. USA: National Defense University, National War College.

Moskos, C. C. (2000). The Media and the Military in Peace and Humanitarian Operations. Chicago: Robert R. McCormick Tribune Foundation.

Noble, R. (2008). Guns, Money, Buildings and Tea: The Enduring CivilMilitary Lessons of Contemporary Operations. Australian Journal of Multidisciplinary Engineering, 6, p. 191-198.

North Atlantic Treaty Organization (2013). NATO Standard Allied Joint Doctrine Civil-Military Cooperation AJP-3.4.9. NATO Standardization Agency, [žiūrèta 2019-09-10]. Prieiga per internetą: https://www.cimic-coe.org/wp-content/ uploads/2014/06/AJP-3.4.9-EDA-V1-E1.pdf

O’Neil, J., Eisenmann, M., Holman, M. (2020). A Mixed Methods Examination of How People Assess the Credibility of Sources Used by Public Relations Practitioners. Journal of Promotion Management. Vol. 26, 75-96.

Šlekys, D. (2015). Intelektualinè refleksija: civilių ir kariškių santykiai Lietuvoje. Lietuvos metiné strateginé apžvalga. 2014-2015, t. 13, p. 215-244.

Zartsdahl, P. H. (2018). Civil-military synergies in EU crisis response and peace building: a frame work for analysis. Denmark: Roskilde University, p. 197-213. 


\title{
THE MEANS APPLICABLE IN CIVIL-MILITARY COOPERATION AND THEIR EFFECTIVENESS
}

\author{
Miglè Nemanytè \\ Lithuanian Duke Vaidotas Mechanized Infantry Battalion
}

Assoc. Prof. dr. Jūratė Guščinskienė

General Jonas Žemaitis Military Academy of Lithuania

\section{Summary}

Over the past few centuries, the norms of civil-military interaction that were established and based on the Western civic thought and political order have changed. This was determined at the beginning of the 21 st century when civilians became participants of war. Currently, the military faces new challenges, such as providing humanitarian assistance operations in the area while maintaining a militarized space and others. Thus, often during a military conflict, the boundaries between non-military and military actors disappear, and civilians become not only victims but also targets.

The problem of the research is defined by the following questions: what means are applied in the cooperation between soldiers and civilians? What is the effectiveness of the civil-military cooperation means? The object of the research is the means of cooperation between soldiers and civilians. The aim of the study is to investigate the means applied in civil-military cooperation and their effectiveness. Objectives of the research: 1) to explain the concept of cooperation between soldiers and civilians; 2) to analyze the importance of cooperation between soldiers and civilians for modern national defence; 3 ) to determine the means of cooperation between soldiers and civilians used in the Duke Vaidotas Mechanized Infantry Battalion (DVMIB) and their effectiveness. Research methods: analysis of scientific literature and legal documents and interviews.

The empirical study (interview) in the DVMIB which was attended by the groups of experts, servicemen and civilians revealed the following: 1) the representatives of all groups unanimously recognized the importance of cooperation between servicemen and civilians in ensuring Lithuania's security; 2) the opinion of all three groups of informants on some measures of civil-military cooperation applied in the DVMIB was the same, i.e. about events, excursions, lectures/educational activities and social networks, however, servicemen and experts also singled out inter-institutional cooperation, while experts noted charitable activities; 3) in the opinion of all groups of informants, excursions were recognized as most effective/best applied means of establishing military relations with the civilians of the DVMIB. 


\section{AUTORIŲ LYDRAŠTIS}

Autoriaus vardas, pavardė: Miglè Nemanytė

Mokslo laipsnis ir vardas:

Darbo vieta ir pareigos: Kunigaikščio Vaidoto mechanizuotasis pėstininku batalionas, būrio vade

Autoriaus mokslinių interesų sritys: karo sociologija

Telefonas ir el. pašto adresas: 86417994; miglea9@gmail.com

Autoriaus vardas, pavardė: Jūratė Guščinskienè

Mokslo laipsnis ir vardas: socialinių mokslų daktarè, docentė

Darbo vieta ir pareigos: Generolo Jono Žemaičio Lietuvos karo akademijos Strateginio valdymo katedros docente

Autoriaus mokslinių interesų sritys: organizacijų sociologija, organizacijų komunikacija, aukštojo mokslo problemos, karo sociologija ir kt.

Telefonas ir el. pašto adresas: jurate.guscinskiene@1ka.lt

\section{AUTHORS' COVER LETTER}

Author's name and surname: Miglè Nemanytė

Workplace and position: Lithuanian Duke Vaidotas Mechanized Infantry Battalion, Platoon Commander

Author's research interests: military sociology

Telephone and e-mail address: +370 641 7994; miglea9@gmail.com

Author's name and surname: Jūratė Guščinskienė

Academic degree and name: Associate Professor, Doctor

Workplace and position: General Jonas Žemaitis Military Academy of Lithuania, Associate Professor

Author's research interests: sociology of organizations, organizational communication, problems of higher education, military sociology

Telephone and e-mail address: jurate.guscinskiene@1ka.lt 